$\xi^{2}=-1$

\title{
Shale volume and permeability of the Miocene unconsolidated turbidite sands of Bonga oil field, Niger delta, Nigeria
}

\author{
Inyang, Namdie .J. *, Akpabio, Idara .O., Agbasi, Okechukwu .E. \\ Department of Physics, University of Uyo, Nigeria \\ *Corresponding author E-mail: namdie007@yahoo.com
}

\begin{abstract}
Bonga oil field is located $120 \mathrm{~km}(75 \mathrm{mi})$ southeast of the Niger Delta, Nigeria. It is a subsea type development located about $3500 \mathrm{ft}$ water depth and has produced over 330 mmstb of hydrocarbon till date with over 16 oil producing and water injection wells. The producing formation is the Middle to Late Miocene unconsolidated turbidite sandstones with lateral and vertical homogeneities in reservoir properties. This work, analysis the petrophysical properties of the reservoir units for the purpose of modeling the effect of shale content on permeability in the reservoir. Turbidite sandstones are identified by gamma-ray log signatures as intervals with 26-50 API, while sonic, neutron, resistivity, caliper and other log data are applied to estimate volume of shale ranging between $0.972 \mathrm{v} / \mathrm{v}$ for shale intervals and $0.0549 \mathrm{v} / \mathrm{v}$ for turbidite sands, water saturation of $0.34 \mathrm{v} / \mathrm{v}$ average in most sand intervals, porosity range from 0.010 for shale intervals to $0.49 \mathrm{v} / \mathrm{v}$ for clean sands and permeability values for the send interval 11.46 to $2634 \mathrm{mD}$, for intervals between 7100 to $9100 \mathrm{ft}$., Data were analyzed using the Interactive Petrophysical software that splits the whole curve into sand and shale zones and estimates among other petrophysical parameters the shale contents of the prospective zones. While Seismic data revealed reservoir thickness ranging from $25 \mathrm{ft}$ to over $140 \mathrm{ft}$ well log data within the five wells have identified sands of similar thickness and estimated average permeability of $700 \mathrm{mD}$. Within the sand units across the five wells, cross plots of estimated porosity, volume of shale and permeability values reveal strong dependence of permeability on shale volume and a general decrease in permeability in intervals with shale volume. It is concluded that sand units with high shale contents that are from 0.500 to $0.900 \mathrm{v} / \mathrm{v}$ will not provide good quality reservoir in the field.
\end{abstract}

Keywords: Bonga Field; Permeability; Porosity; Shale Volume; Turbidite Sand.

\section{Introduction}

The Bonga Oil Field is a subsea development located offshore in the Niger Delta region of Nigeria. The field is operated by Shell Nigeria for Nigerian National Petroleum Corporation (NNPC). The Bonga Deepwater project is under a production sharing contract with partners Esso 20\%, Nigeria Agip 12.5\%, and Elf Petroleum Nigeria Limited $12.5 \%$ (Bonga Field-Wikipedia). The field is in oil prospecting license (OPL) 212, which was renamed in February 2002 as OML 118, and is about $120 \mathrm{~km}$ southwest of the Niger Delta in 1,000 $\mathrm{m}$ depth of water. The producing formation is the Middle to Late Miocene Unconsolidated Turbidite Sandstones (Gaffney, Cline and Associates 2014). The focus of this paper is to evaluate the shale volume and permeability of this unit where it is encountered in the sampled wells.

Sand units in the sample wells are identified by the Gamma-ray $\log$ signatures with values ranging from 26 to 50 API. Turbidite sands show the following features: they are generally thick sequences of regularly inter bedded sandstone and shale. These typically occur in orogenic belts or fault bounded basins. The sand has abrupt basal contact and shows a variety of erosional and deformational structures. Internally, the sand seems to show an upward fining of grain size termed graded bedding (Selly, R.C. 1988). Turbidite according to (Kurniawan, A. et al 2009) is a vertical sequence of sediments deposited by turbidity current. Because the largest particle settles first a turbidite will be graded deposits with coarsest grain size at the bottom and finer grain sizes going upwards. This feature is observed from the Gamma-ray log and vol- ume of shale plot as vertical increase in Gamma-ray log values or shale content.

This work attempts to model and predict some reservoir response within the limits of available data that can assist an operator who needs to know critical reservoir characteristics. According to (Abriel, W.L 2008) there are static and dynamic characteristics. Characteristics before production are static properties, for example, fluid phase (oil and gas percent), areal extent of trap, depth, thickness, compartmentalization, reservoir net to gross and porosity. While dynamic properties include, well deliver ability, reservoir connectivity, permeability, pressure changes, phase changes and reservoir compaction. This work will estimate thickness, depth, porosity, shale volume and permeability of sand units encountered in the well within the depth of known hydrocarbon reservoirs in the field which is usually within and beyond the 7000 feet depth.

\section{Location and geology of study area}

The Bonga field is located $120 \mathrm{~km}(71 \mathrm{mi})$ southwest of the Niger Delta and within the 500m isobaths. It was discovered in 1996 and first production started in November 2005 (Bonga FieldWikipedia). The Bonga field is oil and gas producing field, in 2006, 202,000 barrels per day of oil and $144 \times 10^{6} \mathrm{cu} \mathrm{ft}$ per day of gas was produced.

Seismic information has enabled extensive study of the geology of the Bonga field. In 1993/94 extensive 3D seismic survey carried out in the field led into the discovery of another field in 2001 
called the Bonga SW. In 2004 a third field was discovered, which is now known as Bonga North. Figure 2 shows a typical seismic section through the Bonga field. It shows that the Bonga field is located on the inner fold/ thrust belt. Thrusts and detachment faults are mapped, clearly demonstrating the younger nature of the outer fold and thrust belt compared to the inner belt. The deeper of the two main detachment zones is the one which extends out to the outer belt. The Bonga field in the inner fold and thrust belt is located close to this line, and the structural high is well imaged here; trapping at Bonga is both structural and stratigraphic (Bellingham, P. C. et al 2014).

\section{Location Map}

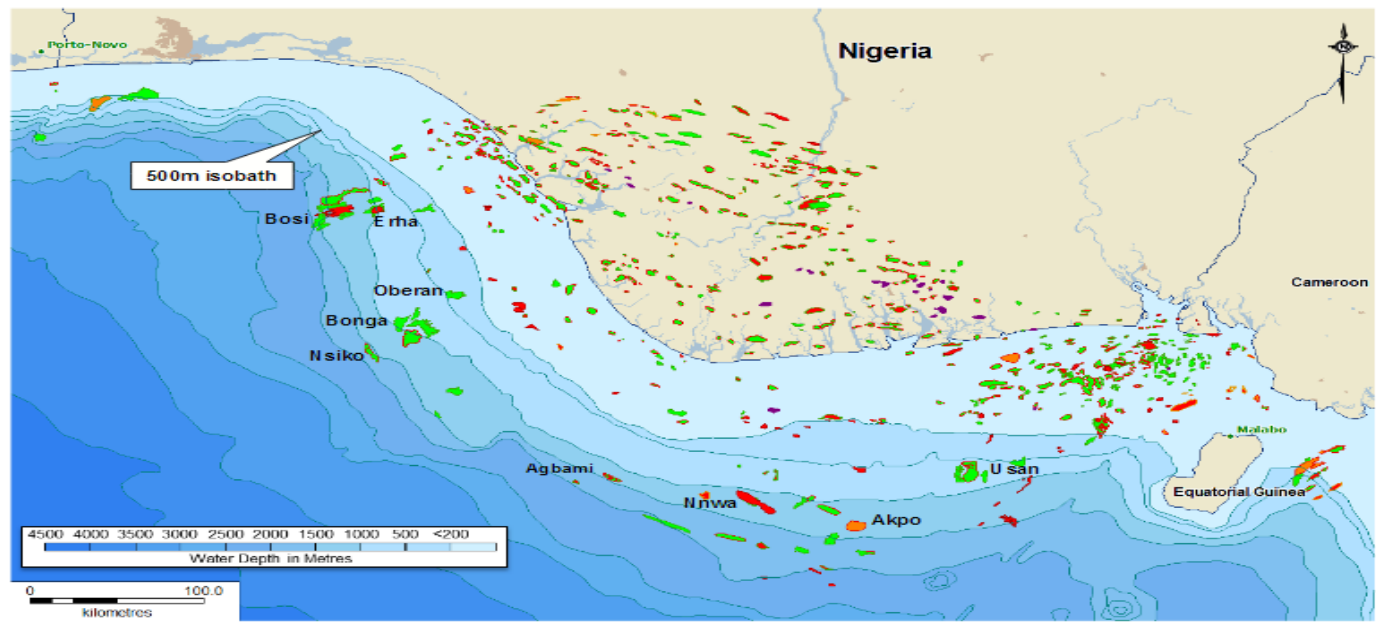

Fig. 1: Location of the Bonga Oil Field.

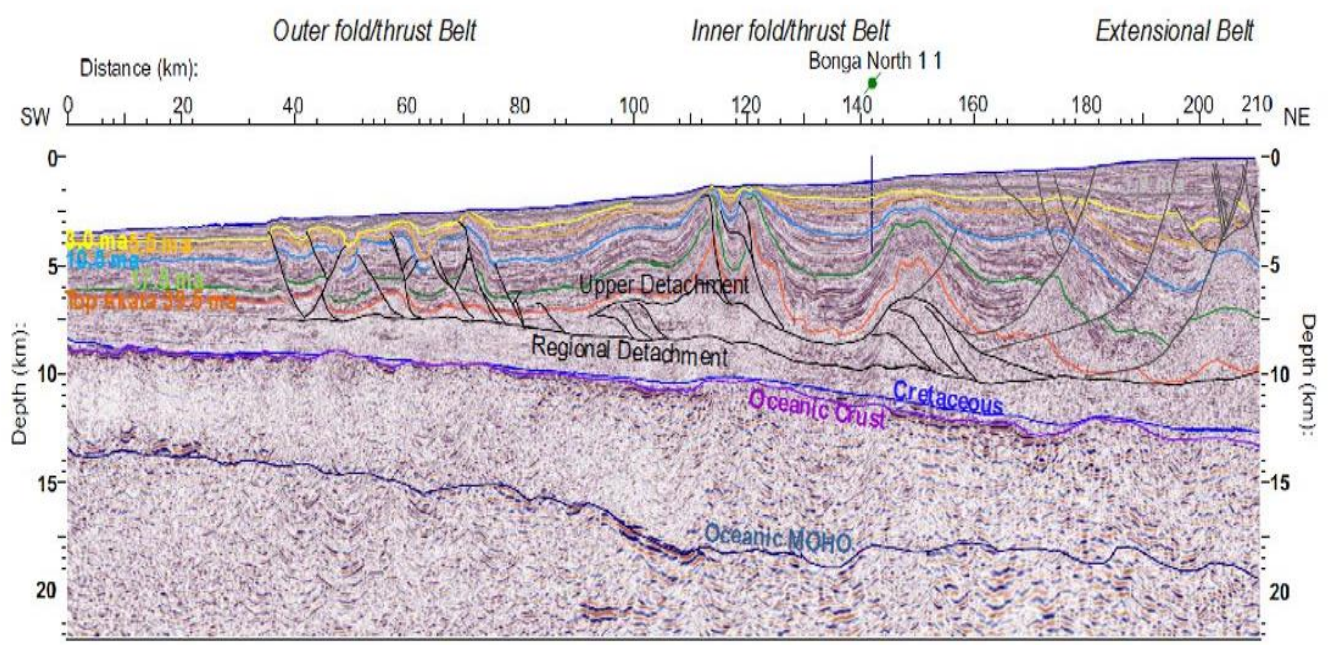

Fig. 2: Regional PSDM Seismic Lines (NG2-4500) Across the Main Provinces of the Niger Delta.

The Tertiary Niger Delta is geologically divided into three formations representing prograding depositional facies distinguished mostly on the basis of sand-shale ratio (Inyang, N. J. et al 2015; Short, K.C et al 1967; Kulke, H. 1995). These three formations are the Benin Formation or Continental Alluvial Sands, the paralic Agbada Formation and the prodelta marine Akata Formation (Akpabio, I. et al 2014: Agbasi, O. E et al 2017).

The Akata Formation is the basal part or unit of the Tertiary Niger Delta complex (Agbasi O. E et al 2013; Mode, A.W and Anyiam, A.O 2007). It is of marine origin and composed of thick shale sequences which on the basis of geochemistry are believed to be the source rock of the Niger Delta petroleum system (Ubong E. E., et al 2017). In the deep water region of the Niger Delta such as the Bonga field, turbidite sandstone with minor amount of clay and silt compose the major reservoir units. The Akata Formation is believed to have formed during low stands when terrestrial organ- ic matter and clays were transported to deep-sea waters characterized by low energy conditions and oxygen deficiency (Inyang, N . J. et al 2015; Starcher, P 1995).

The Bonga is a very large field approximately $60 \mathrm{~km}^{2}$ therefore petrophysical information on reservoir parameters will aid in planning optimal production well location for effective production of hydrocarbon from the field hence this study.

\section{Material and methods}

Wire line log data from five (5) wells in the Bonga field were employed in the study. Figure 3 shows the location of each of the wells use for this study and their relative locations on the grid. 


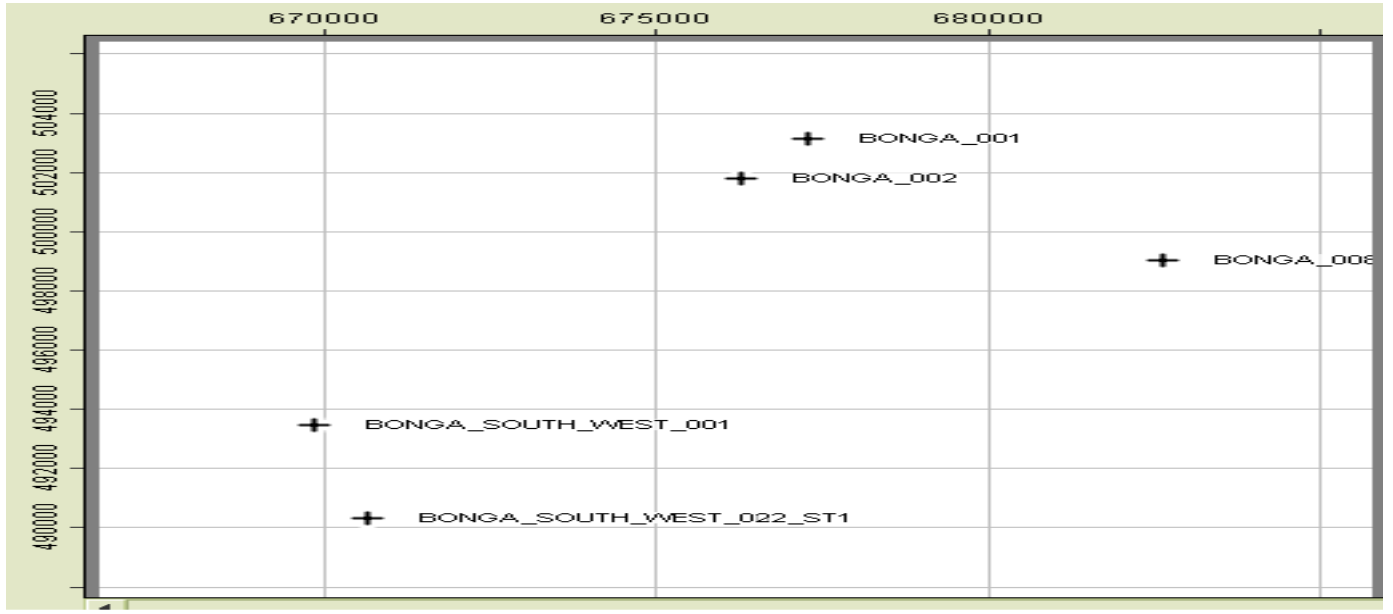

Fig. 3: Well Locations in the Study Area

The log data consisted of Gamma ray logs, sonic logs, neutron logs, resistivity logs and caliper logs. The logs were in the digitized format and in the embedded LAS sequence that is accepted by the processing software.

These $\operatorname{logs}$ were then input to the interactive petrophysical software called Interactive Petrophysics v4.2 which plotted against depth in feet the various logs inputs. From the gamma-ray log, zones were selected that consisted of sand and shale units. Gamma-ray readings of 26 to 30 API were taken as clean sand, while reading of 40 to 70 were accepted as shaly sand, readings of 80 to 110 were taken as sandy shale while readings above 110 to 130 were accepted as pure shale.

Turbidite reservoir sands have upward increment in shale continent and can be simply and qualitatively delineated using the output volume of shale plot calculated from the Gamma ray log.

The sonic logs were employed in the estimation of porosity using the modified Wyllie formula for unconsolidated sandstone (Akankpo, A.O., et al 2015; Wyllie, M.R.J. et al 1956). The equation (that is equation 1) incorporates the compaction correction factor $\mathrm{B}_{\mathrm{cp}}$ and $\mathrm{V}_{\text {shale }}$ estimates.

$\Phi_{s}=\left[\left(\frac{t-t_{m a}}{t_{f l}-t_{m a}}\right) \times \frac{1}{B_{c p}}\right]-\left[\left(\frac{t_{s h}-t_{m a}}{t_{f l}-t_{m a}}\right) \times V_{s h}\right]$

Where $\Phi \mathrm{s}$ is the sonic porosity, $\mathrm{t}$ is the transit time in $\mu \mathrm{s} / \mathrm{ft}, \mathrm{t}_{\mathrm{ma}}$ is the matrix transit time in $\mu \mathrm{s} / \mathrm{ft}$, and $\mathrm{tfl}$ is fluid transit time. The matrix travel time is derived from the

$t_{m a}=\frac{10^{6}}{V_{m a}}$
Where $\mathrm{V}_{\mathrm{ma}}$ is the velocity of sand ( $\mathrm{p}$ wave) in the matrix, $\mathrm{V}_{\mathrm{ma}}$ is expressed as follows

$V_{m a}=\left(K+\frac{0.75 G}{\rho_{m a}}\right)^{0.5}$

$\mathrm{K}$ and $\mathrm{G}$ are the bulk and shear modulus respectively and $\rho_{\mathrm{ma}}$ is the matrix density.

The application of the compaction correction factor avoids the unacceptable high porosities given by the Wyllie et al correlation (Wyllie, M.R.J. et al 1956).

Permeability is estimated by the software using parameters from the Schlumberger equation

$K=a\left(\frac{p h i^{b}}{S_{w i}^{c}}\right)$

Where $\mathrm{k}$ is permeability in $\mathrm{mD}$, phi is porosity and Swi is the irreducible water content of the formation, $a, b, c$ are constants where $\mathrm{a}=1000, \mathrm{~b}=4.5$ and $\mathrm{c}=2$.

Hydrocarbon zones are interpreted by the software using the basic log interpretation module. Results and estimates of shale volume, permeability, sand tops and bottom, porosity, water saturation of each reservoir are shown in tables in next section.

\section{Results and Analysis}

Results from the five (5) wells in the study area are labeled Bonga 1, Bonga 002, Bonga 4, Bonga 8 and Bonga 16 respectively. Values of shale volume, permeability, thickness, water saturation and porosities are shown in the tables below.

Table 1: Parameters for the Reservoir Sand Labeled Sand an in Well Bonga 1

\begin{tabular}{llllll}
\hline TOP (ft) & BOTTOM (ft) & THICKNESS (ft) & PERMEABILITY(mD) & $\begin{array}{l}\text { SHALE } \\
\text { VOLUME } \\
(\mathrm{v} / \mathrm{v})\end{array}$ & $\begin{array}{l}\text { WATER SATURA- } \\
\text { TION(v/v) }\end{array}$ \\
\hline 8039 & 8158.5 & 119.5 & 188.2 & 0.135 & 0.025 \\
\hline
\end{tabular}

Table 2: Parameters for the Reservoir in Well Bonga 2

\begin{tabular}{llllll}
\hline $\begin{array}{l}\text { TOP } \\
(\mathrm{ft})\end{array}$ & $\begin{array}{l}\text { BOTTOM } \\
(\mathrm{ft})\end{array}$ & $\begin{array}{l}\text { THICKNESS } \\
(\mathrm{ft})\end{array}$ & PERMEABILITY(mD) & $\begin{array}{l}\text { SHALE VOLUME } \\
(\mathrm{v} / \mathrm{v})\end{array}$ & $\begin{array}{l}\text { WATER SATURA- } \\
\text { TION(v/v) }\end{array}$ \\
\hline 8900 & 8919 & 19 & 770 & 0.343 & 0.145 \\
\hline
\end{tabular}

Table 3: Parameter for the Reservoir in Well Bonga 4

\begin{tabular}{llllll}
\hline $\begin{array}{l}\text { TOP } \\
(\mathrm{ft})\end{array}$ & $\begin{array}{l}\text { BOTTOM } \\
(\mathrm{ft})\end{array}$ & $\begin{array}{l}\text { THICKNESS } \\
(\mathrm{ft})\end{array}$ & PERMEABILITY $(\mathrm{mD})$ & $\begin{array}{l}\text { SHALE VOLUME } \\
(\mathrm{v} / \mathrm{v})\end{array}$ & $\begin{array}{l}\text { WATER SATURA- } \\
\text { TION(v/v) }\end{array}$ \\
\hline 8325 & 8433 & 108 & 38.42 & 0.276 & 0.027 \\
\hline
\end{tabular}


Table 4: Parameters for Reservoirs in Well Bonga 08 Labeled Sand A and B

\begin{tabular}{llllll}
\hline TOP $(\mathrm{ft})$ & $\begin{array}{l}\text { BOTTOM } \\
(\mathrm{ft})\end{array}$ & $\begin{array}{l}\text { THICKNESS } \\
(\mathrm{ft})\end{array}$ & PERMEABILITY(mD) & $\begin{array}{l}\text { SHALE VOLUME } \\
(\mathrm{v} / \mathrm{v})\end{array}$ & $\begin{array}{l}\text { WATER SATURA- } \\
\text { TION(v/v) }\end{array}$ \\
\hline 9030.5 & 9098.0 & $67.5(\mathrm{~A})$ & 2634 & 0.141 & 0.053 \\
9662.5 & 9723.0 & $60.5(\mathrm{~B})$ & 178 & 0.136 & 0.136 \\
\hline
\end{tabular}

Table 5: Parameters for Reservoirs in Well Bonga 16 Labeled Sand A and B

\begin{tabular}{lllllll}
\hline TOP $(\mathrm{ft})$ & BOTTOM $(\mathrm{ft})$ & THICKNESS $(\mathrm{ft})$ & $\begin{array}{l}\text { PERMEABILITY } \\
(\mathrm{mD})\end{array}$ & SHALE VOLUME (v/v) & WATER SATURATION(v/v) & POROSITY(v/v) \\
\hline 7171 & 7207.5 & 36 & 82 & 0.136 & 0.344 & 0.337 \\
8825 & 8903.5 & 78 & 12 & 0.282 & 0.451 \\
\hline
\end{tabular}

The log interpretation result from the Interactive Petrophysics software for the five wells are shown below in figures 4 to 14

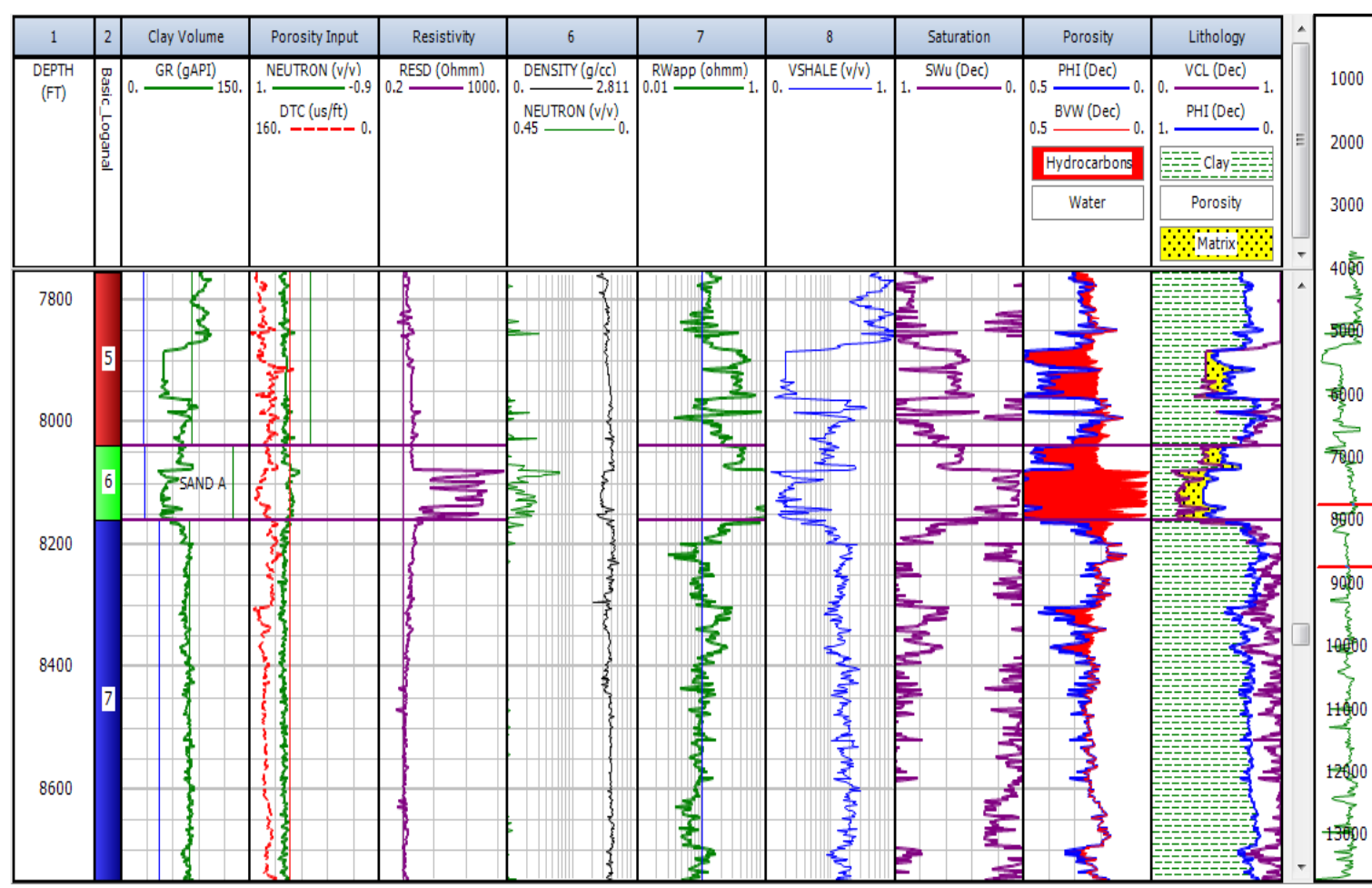

Fig. 5: Log Interpretations for Well Bonga 01 Showing Main Hydrocarbon Bearing Interval (Red Color).

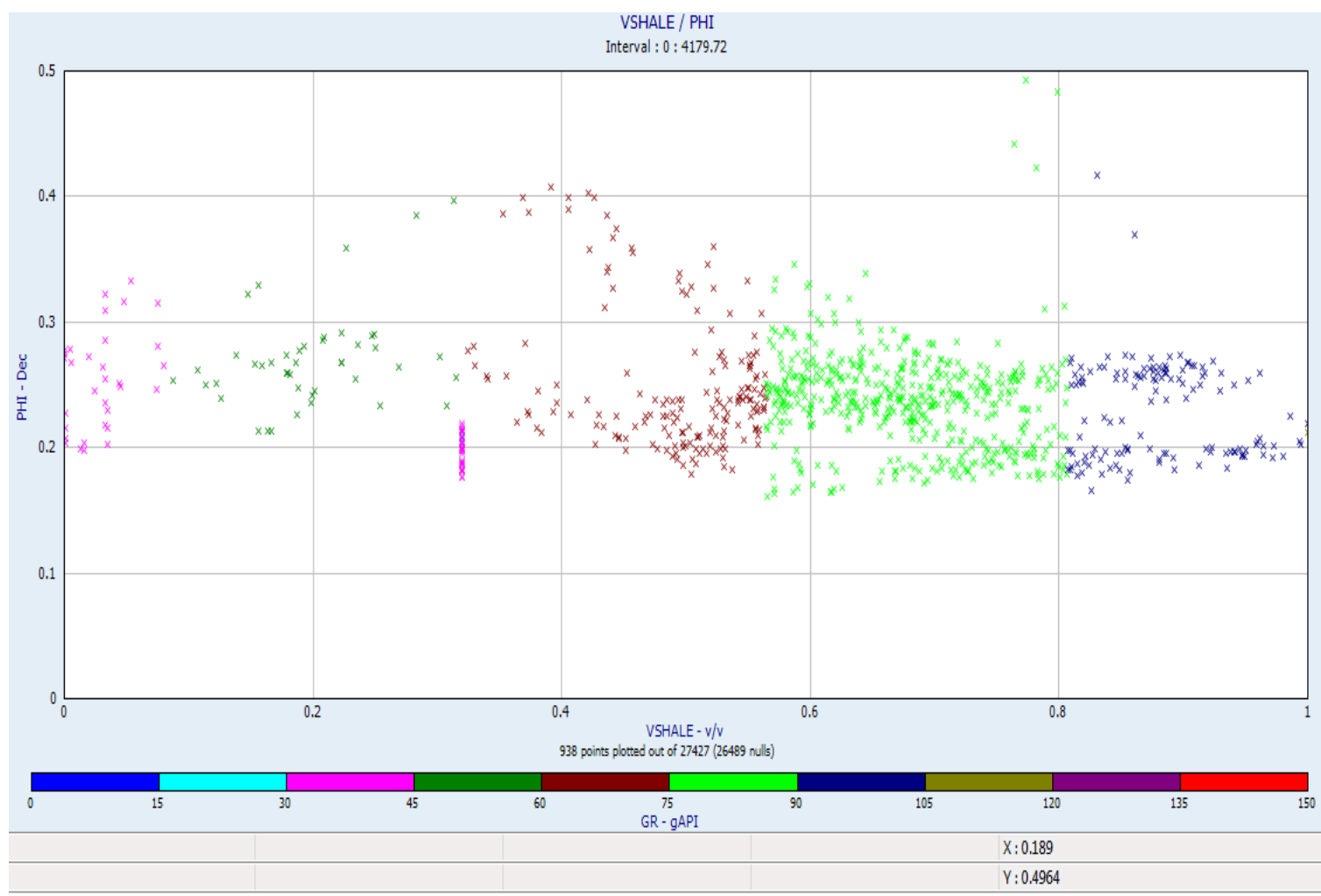

Fig. 6: Cross plot of Porosity and Volume of Shale for Bonga 1 Showing the Range of Porosity Values with $V_{\text {shale }}$ for the Entire Well. 


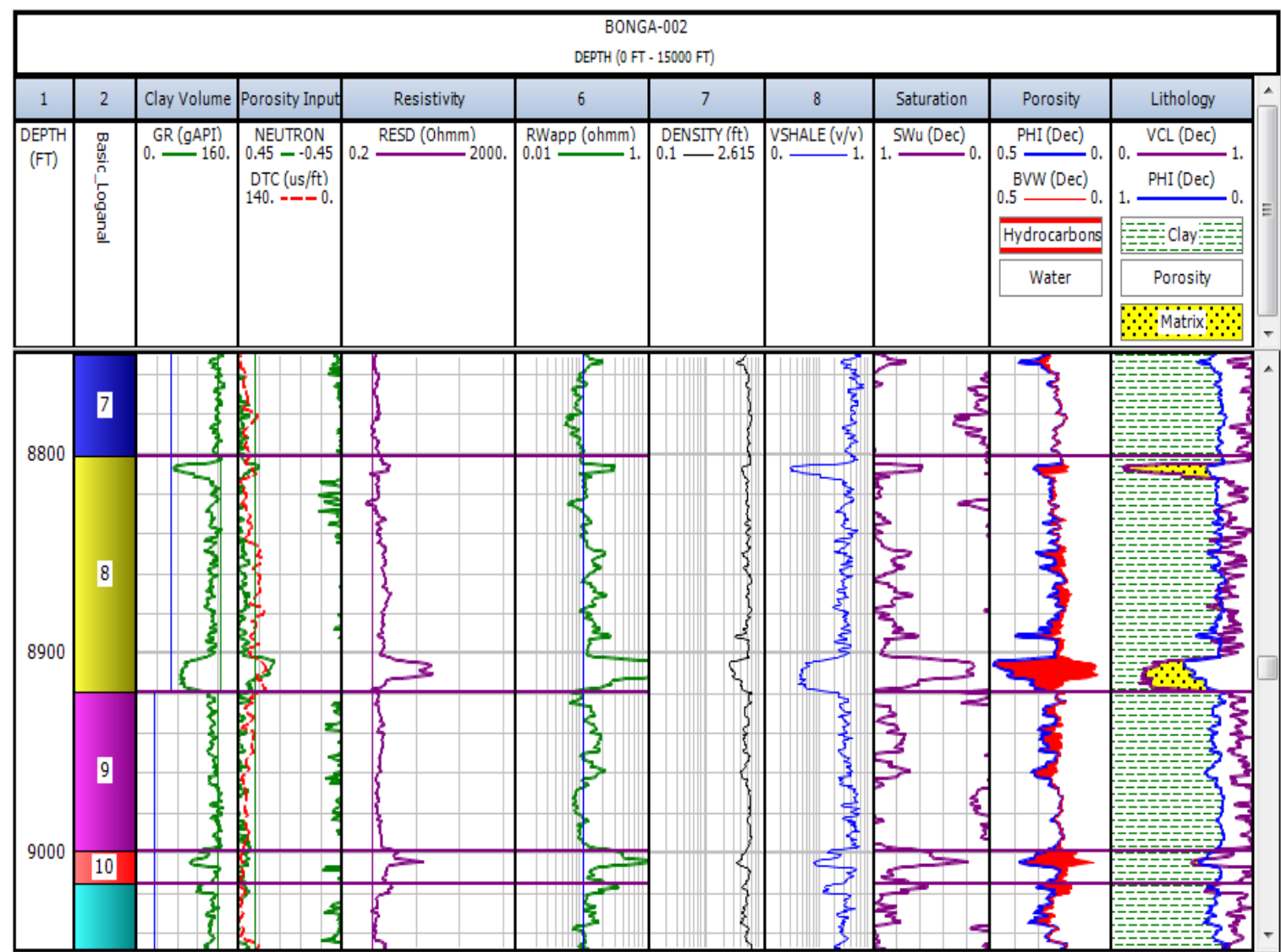

Fig. 7: Log Interpretations for Well Bonga 02 Showing Main Hydrocarbon Bearing Interval (Red Color). Thin Sand with High Permeability Value Is Indicated in Red.

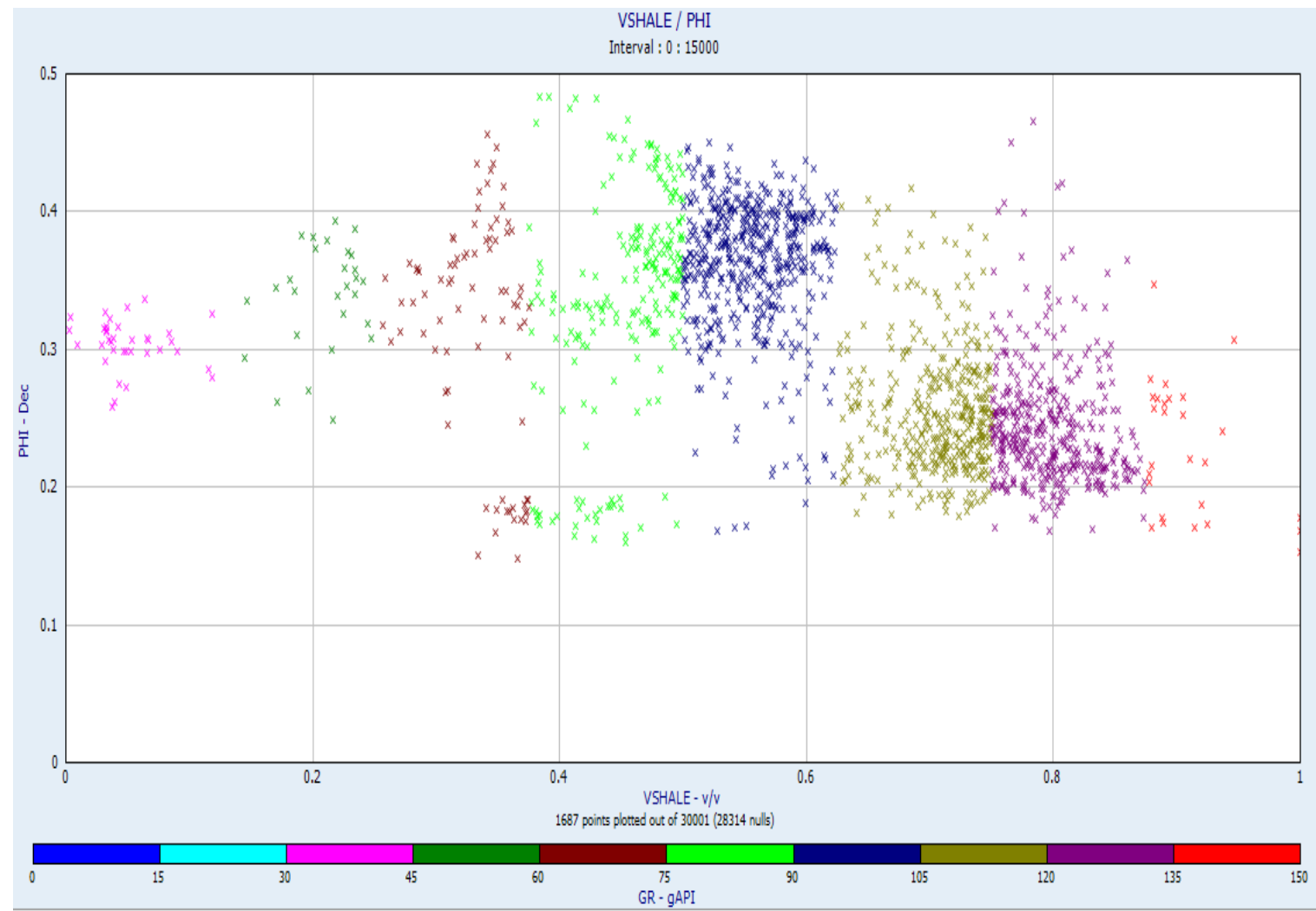

Fig. 8: Cross plot of Porosity with Volume of Shale for the Whole Well Bonga 02 Showing Range of Porosity Values with Highest Porosity at 0.40 to 0.45. Permeability Value at Reservoir Unit Is $770 \mathrm{Md}$. 


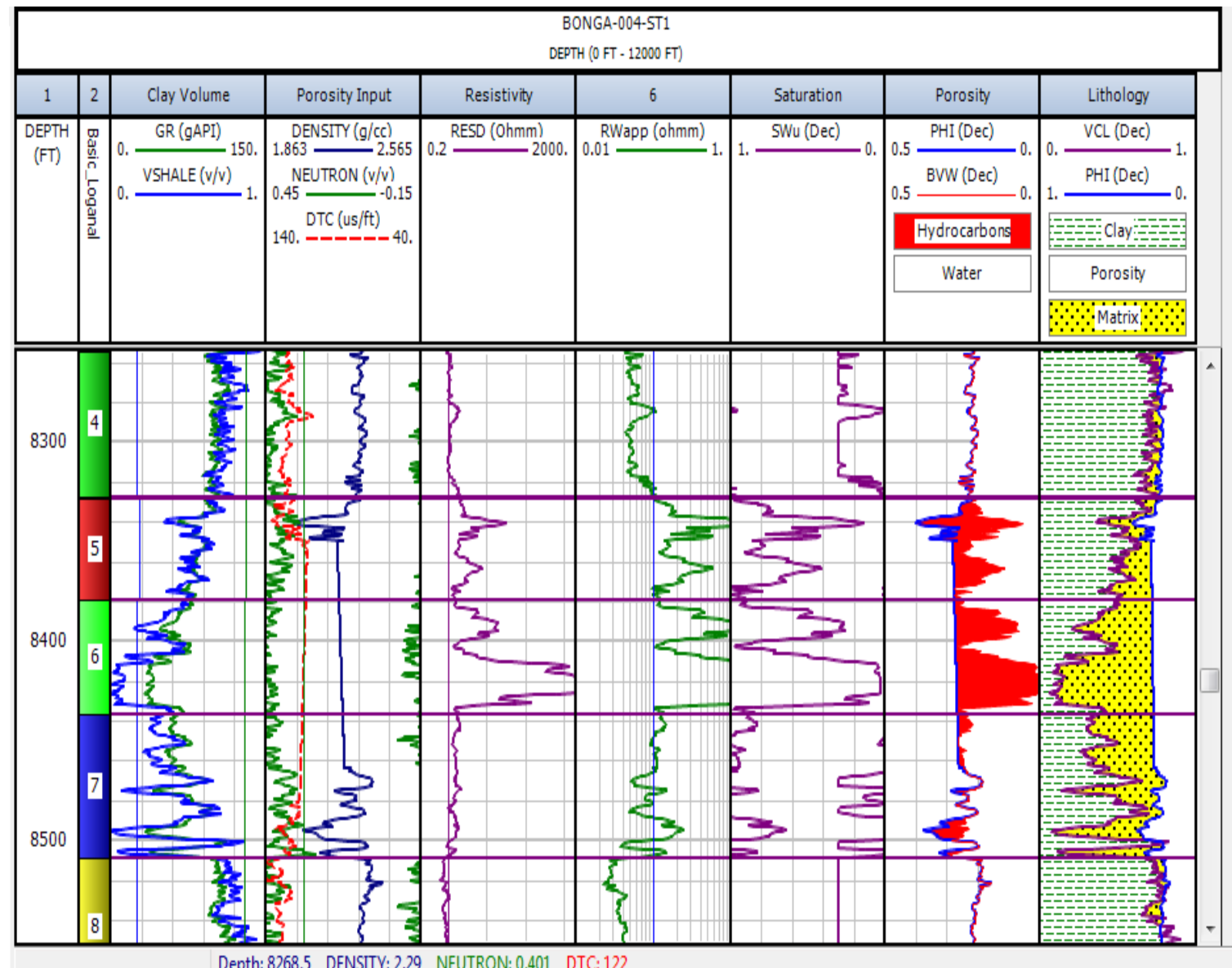

Fig. 9: Log Interpretations for Well Bonga 04 Showing Main Hydrocarbon Bearing Interval (Red Color). Density Data Quality at Reservoir Unit was Unreliable.

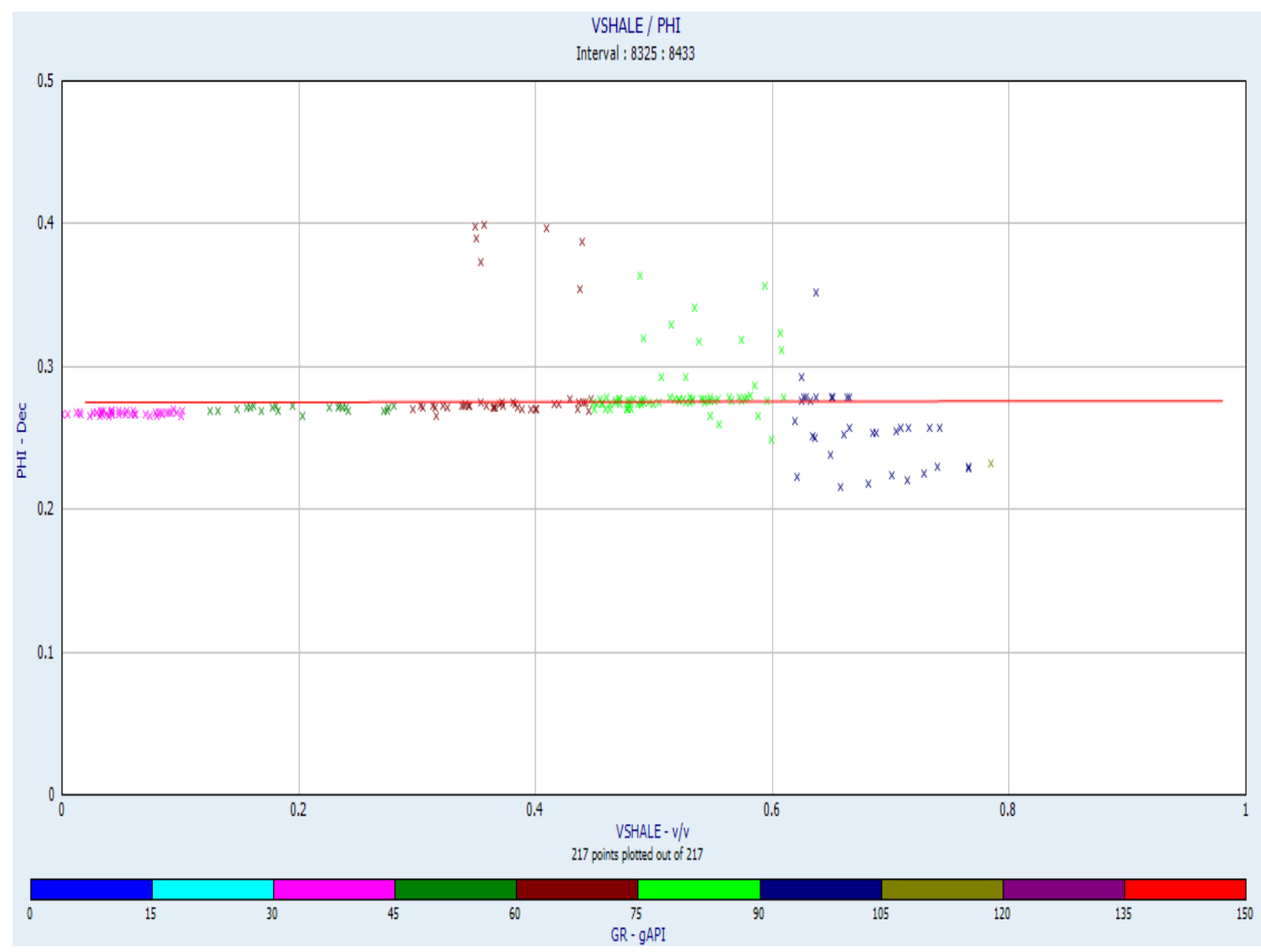

Fig. 10: Cross plot of Porosity with Vshale Showing High Correlation for Clean Sands Up to 58 API Reading. 


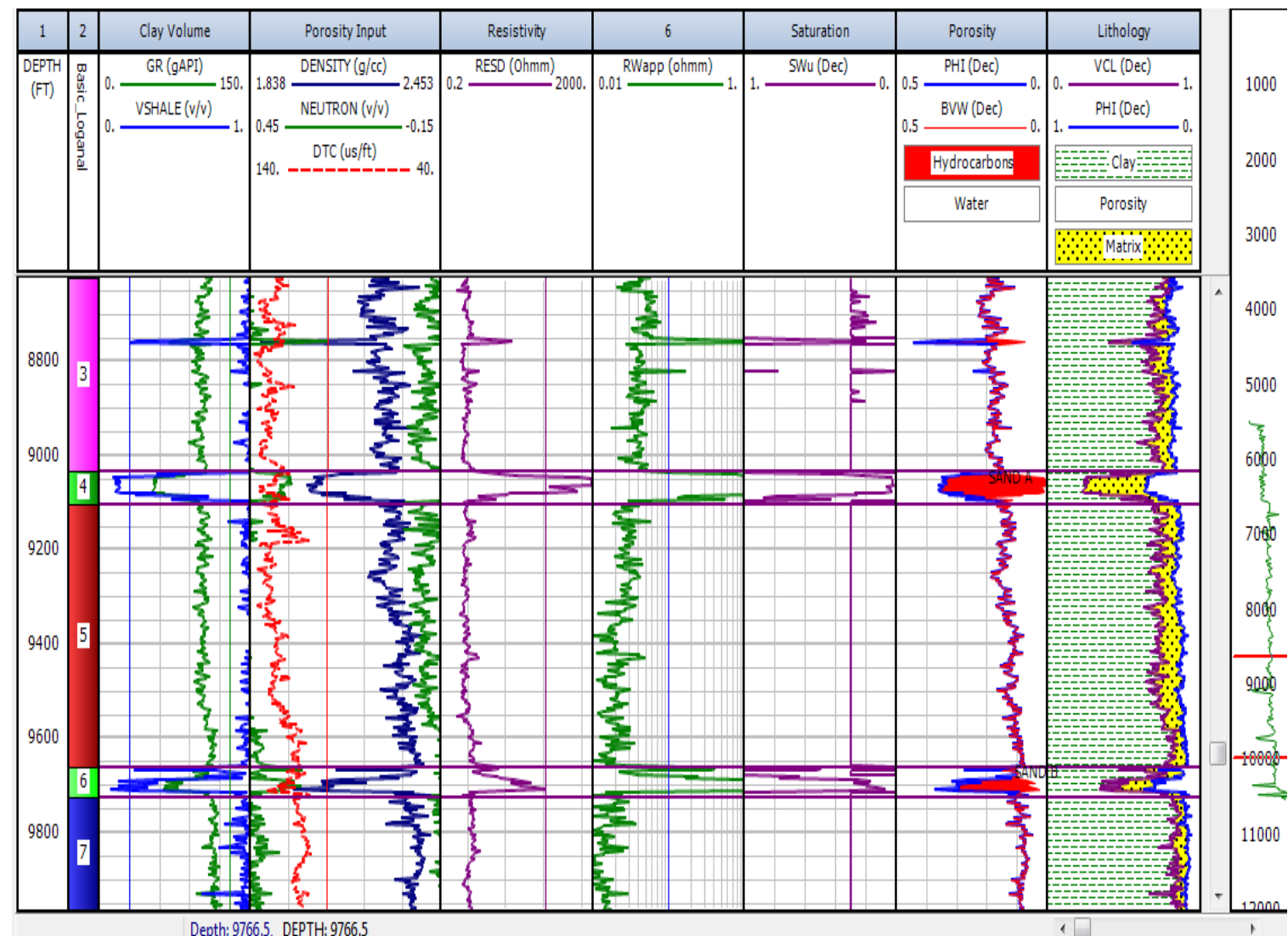

Fig. 11: Log Interpretations for Well Bonga 08 Showing Main Hydrocarbon Bearing Interval (Red Color). This Log Interpretation Shows Evidence of Stacked Reservoir in the Well Location. Sand B Has the Highest Porosity Value for the Five Wells, 2634 Md.

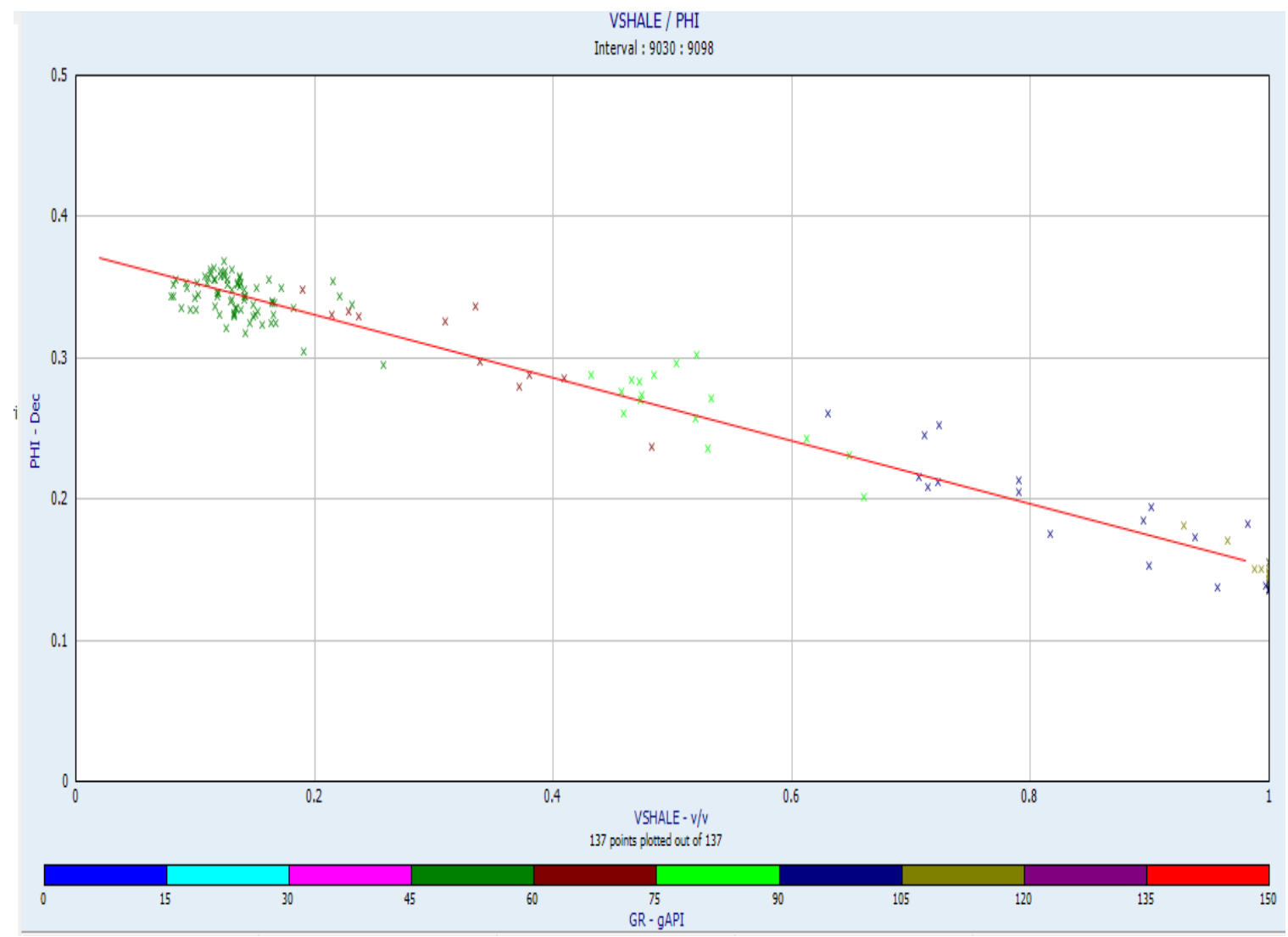

Fig. 12: Cross plot of Porosity with Vshale Showing High Correlation for Sands within the Reservoir Unit. This Reservoir Demonstrates Effect of Shale Content on Porosity and Permeability. 


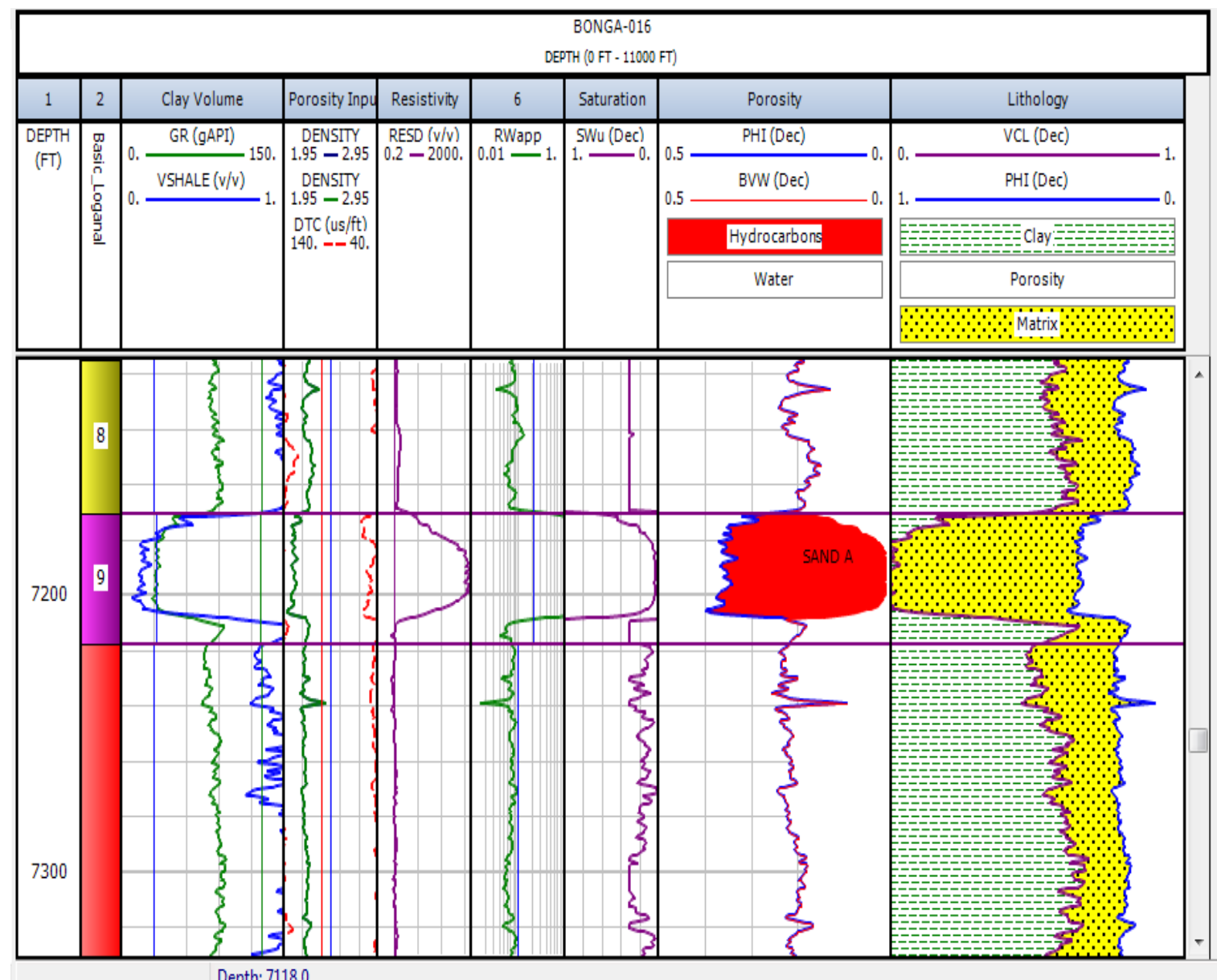

Fig. 13: Log Interpretations for Well Bonga 16 (Sand A) Showing Main Hydrocarbon Bearing Interval (Red Color). This Log Interpretation Shows Evidence of Stacked Reservoir in the Well Location.

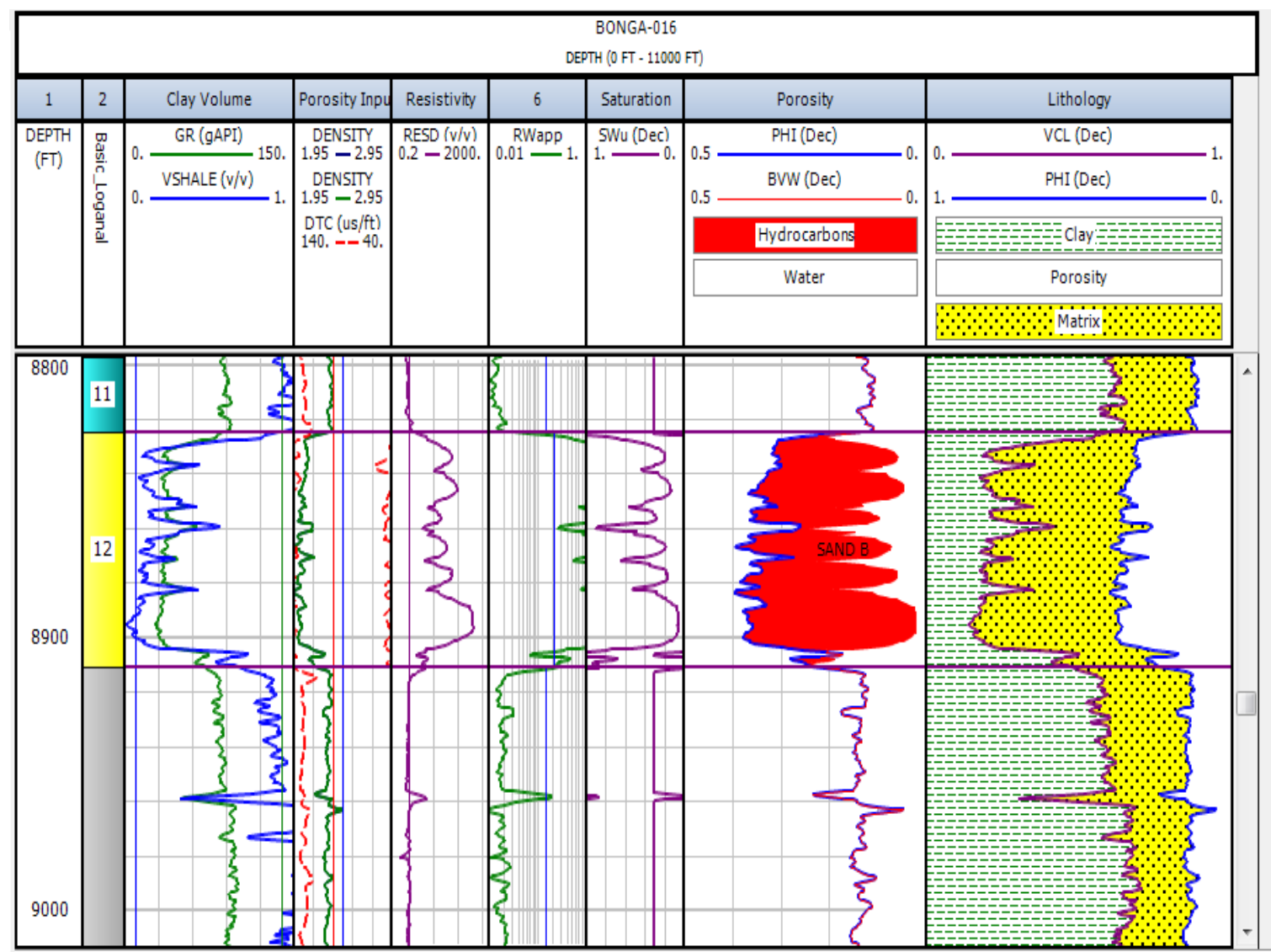

Fig. 13: Log Interpretations for Well Bonga 16 (Sand A) Showing Main Hydrocarbon Bearing Interval (Red Color). This Log Interpretation Shows Evidence of Stacked Reservoir in the Well Location. 


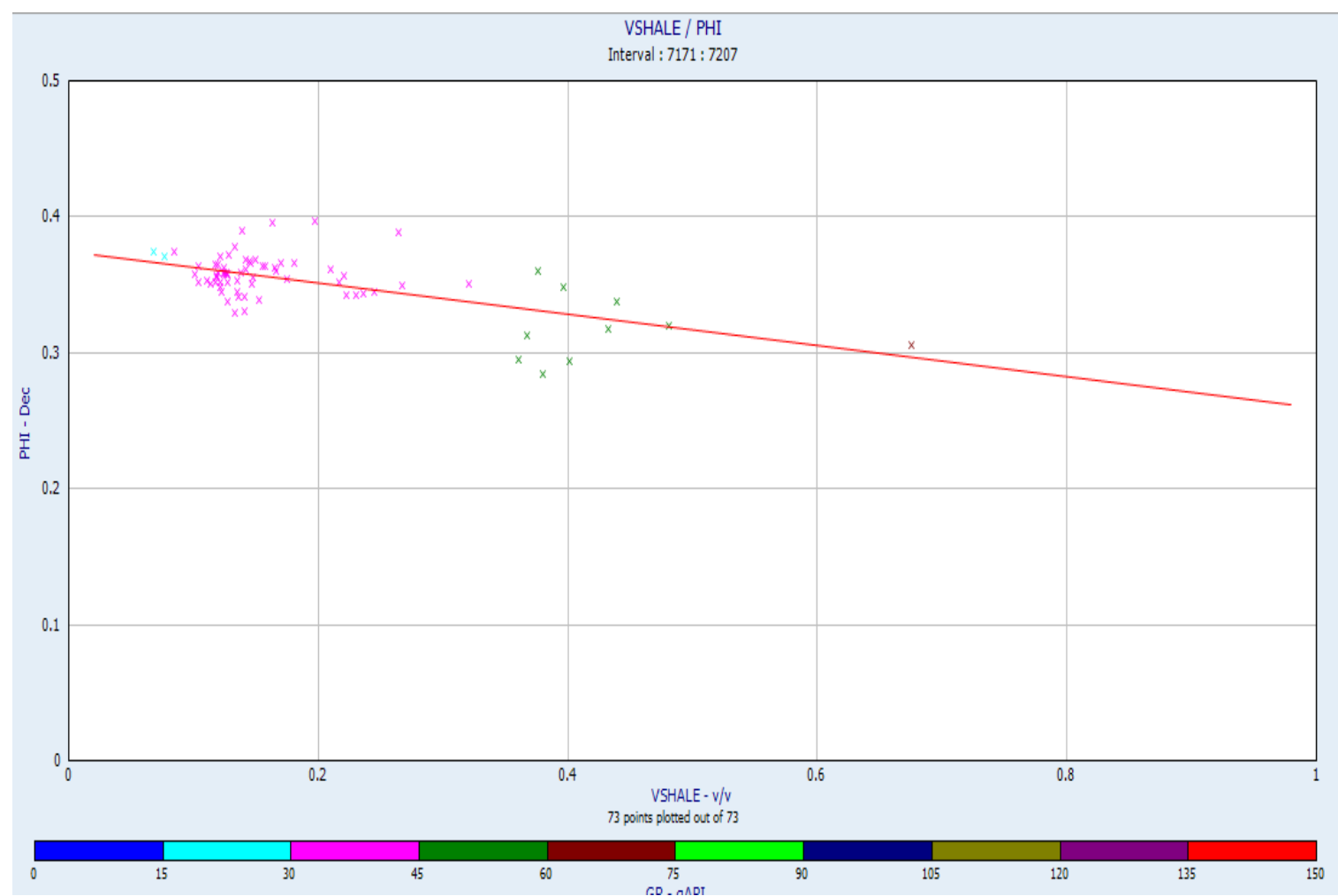

Fig. 14: Cross plot of Porosity and Shale Volume within the Reservoir Unit Showing High Porosity for the Clean Sand Unit.

\section{Conclusion}

The Bonga field is indeed prolific in hydrocarbon content and may exceed the 2022 date of abandonment proposed [13]. Apart from well 04 where data quality was in doubt, hydrocarbon is encountered in almost all the sampled well with meaningful thickness and other petrophysical parameters. The range of permeability is from $12 \mathrm{mD}$ to $2634 \mathrm{mD}$, Shale Volume 0.135 to 0.2343 , Water Saturation from 0.025 to 0.451 and Porosity from 0.270 to 0.490 , across the five (5) wells.

It is concluded that high shale content has effects on first the porosity of the reservoir which in turns affect the permeability values estimated from it and water saturation values. Hence, high shale content in the reservoir units can adversely affect the recovery of hydrocarbon from the well which to a large extent depends on the ability of the reservoir to flow.

\section{References}

[1] Bonga Field-Wikipedia, the free Encyclopedia. http://www.wikipedia.org

[2] Gaffney, Cline and Associates (2014),'West Africa, Deep Water Nigeria: Definition of Stratigraphic Plays"' Royal Institution.

[3] Selly, R.C. (1988) Applied Sedimentology: Academic Press London.

[4] Kurniawan, A. Kenzie, J.M.Putri, J.A (2009) General Dictionary of Geology: Environmental Geographic Student Association.

[5] Abriel, W.L (2008) Reservoir Geophysics: Applications. Distinguish Instructor Series No. 11, EAGE. https://doi.org/10.1190/1.9781560801634.

[6] Bellingham, P. Connors, C. Harworth, R. Radovich, B and Danforth, A. (2014) Deep Water Niger Delta: An Unexplored World-Class Petroleum Province. ION Geophysical Vol.11, No.5.

[7] N. J. Inyang, E. E. Okwueze and O. E. Agbasi, (2015), Detection of Gas Sands in the Niger Delta by Estimation of Poisson's Dampening-Factor (PDF) Using Wireline Log Data, Geosciences, p-ISSN 2163-1697, e-ISSN: 2163-1719, 2015; 5(1): 46-51, doi:10.5923/j.geo.20150501.06.

[8] Short, K.C and Stauble, A.J (1967) Outline of Geology of Niger Delta: AAPG Bulletin, 51:761-770

[9] I. Akpabio, J .C. Ibuot, O. E. Agbasi and O.T. Ojo, (2014), Petrophysical Characterization of eight wells from Wire-line Logs, Niger
Delta Nigeria. Asian Journal of Applied Science, ISSN 2521 0893, volume 02, Issue 02, 105 -109.

[10] Kulke, H. (1995) Nigeria, In H, Kulke. (Ed.) Regional Petroleum Geology of the World. Part II: Africa, America, Australia, and Antarctica: Berlin, Gerbrunder Borntragaer, p. 143-172.

[11] O. E. Agbasi, N. Inyang and J. Ibout, (2013), Estimation of Water Saturation in Niger Delta Nigeria Using Wire-Line logs. IOSR, Journal of Applied Physics (IOSR-JAP). e-ISSN: 2278 - 4861, volume 3, issue 4(2013) pp.66 -71. www.iosrjournals.org.

[12] Ubong E. Essien, Akaninyene. O. Akankpo and Okechukwu. E. Agbasi (2017). Evaluation of Reservoir's Petrophysical Parameters, Niger Delta, Nigeria. International Journal of Advanced Geosciences, 5 (1) (2017) 19-25. https://doi.org/10.14419/ijag.v5i1.7456.

[13] O. E. Agbasi, A. O. Akankpo and U. E. Essien (2017).Estimation of Reservoir Potentials of Two Wells in Niger Delta Region, Nigeria. Journal of Geosciences and Geomatics, 2017, Vol. 5, No. 2, 87-95.

[14] Mode, A.W and Anyiam, A.O (2007) Reservoir Characterization: Implications from Geophysical Data of "'Paradise-Field" Niger Delta, Nigeria.

[15] Starcher, P (1995) Present Understanding of the Niger Delta Hydrocarbon Babitat: Shell Development Company of Nigeria Ltd, Warri.

[16] Wyllie, M.R.J. Gregory, A.R and Gardner, L.W (1956) Elastic Wave Velocities in Heterogeneous and Porous Media. Geophysics 2(1):41-70. http://dx.doi.org/10.1190/1.438217.

[17] Akankpo, A.O., Umoren E.B., Agbasi O.E., (2015). Porosity Estimation Using Wire-Line Log to Depth in Niger Delta, Nigeria. IOSR Journal of Applied Geology and Geophysics (IOSR-JAGG) $e$ ISSN: 2321-0990, p-ISSN: 2321-0982.Volume 3, Issue 4 Ver. II (Jul - Aug. 2015), PP 31-38 www.iosrjournals.org. 